(С) Пригодін М.Д., 2019 р.

https://orcid.org/0000-0002-6891-8585

DOI: $10.34142 / 23128046.2019 .46 .09$

М. Д. Пригодін

\title{
ОСОБЛИВОСТІ ФОРМУВАННЯ ТВОРЧИХ УМІНЬ МАЙБУТНІХ УЧИТЕЛІВ ОБРАЗОТВОРЧОГО МИСТЕЦТВА В ПРОЦЕСІ АНАЛІЗУ ТВОРІВ МИСТЕЦТВА
}

У статті розкриваються особливості формування творчих умінь майбутніх учителів образотворчого мистецтва (ОБМ) у процесі аналізу творів мистецтва як ефективний засіб їх сформованості. Творчі уміння обумовлюють самостійне мислення, генеруючи оригінальні ідеї, створюючи творчий продукт або художній твір. Засіб формування творчих умінь майбутніх учителів ОБМ здійснюється в концепції - «реконструкиія» застарілих методів, через аналіз творів мистецтвва з урахуванням поліхудожніх функцій кожного вміння. 3'ясовано, щзо для форммування творчих умінь з образотворчого мистецтва у студента має бути «культурний шар» - першочергові навчальні знання, уміння й навички, щуо потрібно постійно збагачувати. Заклад вищої освіти зобов'язаний надати знання, зокрема, творчі вміння в усіх галузях образотворчого мистецтва. Аналіз творів мистецтва є важливим чинником культури художнього відтворення, щзо впливає на формування творчих умінь майбутніх учителів. Ці вміння реалізуються низкою чинників, а саме: функціональних, композиційних, аналітичних, соціальних, біонічних, технологічних. Формуванню творчих умінь з образотворчого мистецтвв сприяють наукові підходи, як-от: культурологічний, діалоговий, полісуб'єктний, синергетичний, середовищуний, виставковий. Отже, збагатити власні творчі вміння можливо, виконуючи обгрунтований аналіз і синтез творів вітчизняних та зарубіжних художників, зокрема імпресіоністів, які визначили виникнення передової револючійної течї як відтворення емоиійного сприйняття світу. Це дає можливості зрозуміти філософію нового напряму в образотворчому мистецтві - «імпресіонізм». Спостерігаючи світ, імпресіоністи побачили його в динамічному розвитку й прагнули передати феномен враження.

Аналізуючи різні твори мистецтва, ми опановуємо творчість видатних митців, збагачуючи власні творчі вміння. Таким чином, проводячи наукові дослідження формування творчих умінь майбутніх учителів образотворчого мистецтвва, нами визначено иість творчих умінь, збагачених власними творчими вміннями. Ці творчі вміння є ефективними й універсальними, можуть використовуватись як базові для образотворчого й декоративного мистец̧тва зі спеціалізацій: розпис, кераміка, батик тощуо. 
Творчі вміння майбутні вчителі ОБМ реалізують у художньо-педагогічній діяльності, допомагаючи школярам саме через творчі вміння виконувати навчальні та творчі завдання.

Ключові слова: творчі вміння, учитель образотворчого мистецтва, художні иінності, педагогічний вищу, європейська інтеграція.

Prihodin M. D. Features of forming creative skills of future teachers of fine arts in the process of of art works analysis. The article covers the analysis of works of art - a means in the formation of creative skills of future teachers of fine arts in the process of art works analysis as an effective approach. Creative skills make independent thinking, generating original ideas, creating a creative product or artwork. The factor shaping the creative skills of future teachers (OBM) is carried out in the concept - «deconstruction» of outdated methods, through analysis of works of art, taking into account the functions of each creative skill. For the formation of creative skills in fine arts, a student must have a «cultural layer» - the primary learning knowledge, skills and skills that need to be constantly enriched. Higher education institution is obligated to provide knowledge, creative skills to all branches of fine arts. Analysis of works of art is an important factor in the culture of artistic reproduction, which influences the formation of creative skills of future teachers, which are implemented by a number of factors, such as: functional, compositional, analytical, social ,. bionic, technological, which is based on scientific approaches: culturological, dialogue, polysubject, synergetic. environmental, exhibition and activity. Thus, enriching one's own creative skills is possible by performing a substantiated analysis and synthesis on examples of works of domestic and foreign artists who have identified the emergence of a revolutionary trend that gives the opportunity to understand the philosophy of a new direction in fine art - «impressionism». The Impressionists tried to find their own ways in art. Watching the world, they saw him in a dynamic development - to convey the phenomenon of impression. Each artist had an individual pictorial language, an impression, but not an academic classics.

Summarizing the foregoing, we note that analyzing various works of art, we master the creativity of outstanding artists, own the secrets of artistic skill that they discovered, enriching their own creative skills. Thus, by conducting scientific researches on the formation of creative skills of future teachers of fine arts, we have identified six creative skills, enriched by our own creative skills, with polyartistic functions that realize artistic and aesthetic values. These creative skills are effective and versatile, can be used as basic fine arts and decorative arts of specialization: painting, ceramics, batik, etc. The creative skills of future teachers of OSH are implemented in artistic and pedagogical activities, moking an ecoenergy-saving product; helping students develop creative skills that perform educational tasks.

Keywords: creative skills, teacher of fine arts, artistic values, pedagogical education, eurointegration. 
Вступ. Учитель у своїй педагогічній діяльності реалізує державну політику в освіті для виховання творчої особистості, конкурентоспроможної на ринку праці, збагаченої знаннями, навичками й творчими вміннями, серед яких творчі вміння є одними 3 провідних і визначальних. Творчі вміння вчителя обумовлюють самостійне мислення, завдяки їм, генеруючи оригінальні ідеї, він створює творчий продукт або художній твір (Programa rozvytku vishchoi osvity Ukrainy «Osnovni zasady rozvytku vishchoi osvity Ukrainy», 2008). Незважаючи на дослідження науковців, тему 3 питань сформованості творчих умінь ще повною мірою не висвітлено в педагогічній теорії та практиці.

Так, освітні концепції художньої творчості розробляються як українськими (Є. Антонович, В. Бутенко, І. Зязюн, О. Рудницька, О. Шевнюк та ін.), так і зарубіжними (М. Ростовцев, С. Шорохов, О. Яшухін та ін.) науковцями. Питання психолого-педагогічних процесів навчання досліджувала Н. Лисенко (Lysenko, 2018), професійні вміння - С. Сисоєва (Sysoeva, 2006), художню культуру - О. Щолокова (Shcholokova, 2017). Разом iз тим, зазначені питання вивчалися нами на творах вітчизняних та зарубіжних митців: О. Мурашко, М. Пимоненко, І. Репін, Т. Яблонська, I. Марчук. Зокрема, нас цікавила творчість імпресіоністів - Е. Дега, К. Моне, О. Ренуара, А. Сислея та ін.

Мета та завдання. Висвітлити особливості формування творчих умінь майбутніх учителів образотворчого мистецтва через аналіз творів мистецтва, як одного із ефективних засобів їх сформованості.

Методи дослідження. У дослідженні використані теоретико-практичні методи формування творчих умінь майбутніх учителів образотворчого мистецтва, що здійснюються в концепції «деконструкції» застарілих методів, i новий «аналітично-критичний» метод для об'єктивного аналізу творів мистецтва із урахуванням поліхудожніх функцій кожного творчого вміння, що віддзеркалюють художньо-образний зміст і форми його відображення 
(майстерність, передача характеру й емоцій персонажів, стану природи, а також образності й цілісності твору).

Результати. Узагальнюючи різні погляди науковців із питань художньо-педагогічної творчості (Є. Антонович, В. Бутенко, I. Мужикова, О. Рудницька, С. Сисоєва, О. Шевнюк, О. Щолокова), нами визначено феномен «творчі вміння», як можливість успішно виконувати трудову діяльність або дії, причому оригінальним, неповторним способом, виявляючи інновації, винахідливість, використовуючи знання, навички i досвід, які отримані в закладі вищої освіти. Для формування творчих умінь 3 образотворчого мистецтва у студента повинен бути «культурний потенціал», якій потрібно постійно збагачувати власними зусиллями.

Водночас, формування творчих умінь майбутніх учителів вимагає використання таких наукових підходів, як: культурологічний, діалоговий, полісуб’єктний, синергетичний, середовищний (біонічний), виставковий.

Важливими напрямами опанування художніми дисциплінами стають культурологічна спрямованість i діалогове спілкування. Як зазначає О. Щолокова (Shcholokova, 2017), звернення до теоретичних положень художньої культури дозволяє включати в освітній процес такі категорії та поняття, як «художня картина», «творчий метод», «творчі здобутки». Завдяки культурологічному й діалоговому підходам стає зрозумілим вплив художніх засобів на творчі вміння. На думку фахівця, естетична оцінка є одним із важливих засобів формування творчих умінь. Перелічимо ці засоби.

1. Функціональний, котрий передбачає аналіз творів мистецтва, визначення функцій творчого вміння як поліхудожніх, наповнення художніми образами змісту і форм їх відображення, набуття практичного досвіду й уміння передавати його студентам;

2. Композиційний - побудова композиції твору здійснюється засобами гармонізації, де створення об’ємно-просторової структури реалізуються законами підпорядкованості, тектоніки, цілісності й образності.

3. Аналітичний - генерація ідей, народження нового задуму та 
тематики композиції твору, використання індукції і дедукції, аналізу й синтезу, підсвідоме поєднання інтуїції з формулою аналітичного мистецтва;

4. Соціальний - співпраця у системі «студент-викладач», створення комфортної творчої атмосфери навчального процесу, колективне розв’язування суперечностей, рефлексія самооцінки власних творчих умінь.

5. Біонічний, що характеризує шляхи використання фрагментів природи в мистецтві, трансформуючи біонічні форми в художню ситуацію, відтворюючи красу природи, їі міцність, пристосованість й корисність, як кращій художник.

6. Технологічний - передбачає процес виготовлення речей iз застосуванням комп’ютерних технологій, виготовлення екоенергозбережувального продукту.

3 метою реалізації перелічених засобів студентам на методологічних засадах із урахуванням самостійного аналізу творів мистецтва пропонується побудувати організаційно-методичну модель формування творчих умінь.

Як свідчить проведене дослідження, збагаченню творчих умінь студентів сприяє аналіз художніх творів. Розкриємо це на прикладах творів вітчизняних художників, які визначили в мистецтві новий напрям «критичний реалізм».

1. Наприклад, необхідно визначити головне, другорядне, створюючи художні образи на полотні I. Рєпіна «Запорожці пишуть листа до турецького султану». Це один із найяскравіших творів художника на історичну українську тематику 3 ідейним задумом - визвольна війна українського народу проти поневолення. Митець створює образи козаків, які сильні духом, не бояться турків, готові до нових боїв за кращу долю, посміхаються - вони непереможні (уміння визначати головне, створюючи художні образи).

2. Пропонується проаналізувати гармонійну цілісність твору пам’ятник Т. Шевченку, м. Харків (скульптор М. Манізер). Завдання достатньо складне і автор на високому художньо-професійному рівні його розв’язує. Художник поєднує зображення стоячих й напівсидячих 
персонажів, їх ракурси, емоційні почуття. 3 правого боку композиції зображені ті, хто висловлює протест пригноблення, хто стогне в злиднях тяжкої кріпацької долі, хто образно відображає кріпацтво; із лівого боку представлені персонажі радянського періоду: робітник, колгоспник, солдат та комсомолка-активістка. Об’єднуючим композиційним центром виступає фігура поета Т. Шевченка, мужнього борця за кращу долю українського народу. Скульптор відтворив чудові художні образи, розкрив динаміку i настрої героїв. Це найкращій пам’ятник на рівні світового шедевра (уміння аналізувати).

3. Уміння формулювати гіпотезу здійснювалось на прикладі аналізу ікони «Богородиця», яка завжди була моральним та духовним надбанням українського народу. Ікона має надзвичайну енергетичну силу, захищає людину, зупиняє ворога, перемагає зло. Художник в образі Марії відтворив усю досконалість: «Святий дух зійде на тебе». I Марія з вдячністю сприймає цю звістку щодо народження спасителя Всесвіту - Ісуса Христа (уміння висувати гіпотезу).

4. Співпраця студентів 3 викладачем добре представлена Т. Яблонською під час написання картини «Хліб». Картина заслуговує пошани нашого народу. Зі слів автора, вона збирала для картини матеріал у полтавському селі Летава, де була у тісному контакті, співпрацювала 3 майбутніми персонажами твору - колгоспниками, постійно їх замальовувала. Часто позували і студенти, вважали це за гідність, набиралися практичного досвіду, відпрацьовували власні вміння (уміння співпрацювати).

5. Трансформацію біонічних форм у художню ситуацію можна побачити на картині народного художника I. Марчука «Зимовий пейзаж». Мерехтіння світла місяця, яке простежується разом із засніженими ланами, 3 розкиданими копицями соломи, загадковим лісом, із зображенням окремих домівок села, вселяє надію на оновлення життя, відтворення нового образу пейзажу (уміння трансформувати природничі форми в художні зображення). 
6. Застосовувати інноваційно-комп'ютерні технології для виготовлення рекламної художньої продукції - потреба суспільства. Продукт виготовляється на технологічному обладнанні, швидко, якісно, естетично. Оволодіння творчими вміннями можливо, застосовуючи комп'ютерні технології: «Color Draw», «Photoschop» (уміння застосовувати технологіï).

Аналіз творів мистецтва зарубіжних художників надає можливість зрозуміти філософію нового напряму в мистецтві - «імпресіонізм».

Так, К. Моне визначився 3 уміннями, які потрібні для написання пейзажів. У природі він бачив споконвічне життя, насолоду. Створював новий художній образ природи в пейзажах, наприклад, картини «Враження. Сонце, що сходить», як перемогу в мистецтві «імпресіонізму» (уміння пропонувати гіпотези та трансформувати природні форми в художні).

Зачарований у природу А. Сислей, малює пейзажі 3 проробкою тонкощів мерехтіння листя дерев, кущів, хмаринок у небі, берегів річки, 3 яскравим віддзеркаленням їх у воді - ліричний настрій картини «Повідь у Марлі» (уміння створювати цілісність).

Талановитий О. Ренуар розкривав життя у всіх його проявах: писав пейзажі, портрети, багатофігурні композиції. Митець створює образи чарівних жінок у емоційному стані, поєднує класичні пропорції зображення 3 концепцією «імпресіонізму». Наприклад, у картині «Сніданок човнарів» (уміння співпрацювати).

Зміст творів Е. Дега свідчить про індивідуальний, своєрідний підхід художника до теми великого міста. Митець зображує співачок, артисток цирку, що вказує на віртуозне володіння ним технікою імпресіонізму (уміння застосовувати технології).

Разом із тим, студенти знайомляться з витоками творчої спадщини Національного музею народного мистецтва України, опановуючи творчий потенціал, здійснюючи копії з творів народних майстрів (М. Примаченко, К. Білокур, Ф. Панка та ін.). Поділяємо думку проф. Н. Лисенко, що виховний ідеал сьогодні пронизують естетичні стратегії, сприяє формуванню 
творчості, розвитку здібностей засобами народних ремесел і промислів, вихованню людини (Lysenko, 2018).

Таким чином, проводячи дослідження формування творчих умінь майбутніх учителів образотворчого мистецтва, нами визначені сім творчих умінь із поліхудожніми функціями, які реалізують художні цінності, а саме:

1. Уміння визначати головне й другорядне, опановуючи майстерність і відтворюючи художні образи.

2. Уміння аналізувати і синтезувати твори мистецтва, відтворюючи емоції персонажів, стан природи та гармонійну цілісність твору.

3. Уміння пропонувати гіпотези, оригінальні ідеї, порівнювати і протиставляти дані, поєднуючи інтуїцію з аналітичним мистецтвом.

4. Уміння співпрацювати в системі «студент-викладач», розв’язуючи суперечності і здійснюючи рефлексію власних творчих умінь у педагогічній діяльності.

5. Уміння трансформувати біонічні форми в художні формоутворення, проводячи експериментальні дослідження.

6. Уміння застосовувати комп'ютерні технології, і зокрема, творчий досвід науковців, виготовляючи еко-енергозбережувальний продукт.

7. Уміння реалізовувати сформовані творчі вміння майбутнього вчителя в художньо-педагогічній діяльності, об’ єктивно їх обгрунтовувати.

Обговорення. Проведене дослідження дозволило доповнити погляди науковців щодо особливостей формування творчих умінь майбутніх учителів образотворчого мистецтва в процесі аналізу творів мистецтва. Обравши художньо-педагогічну діяльність, нами визначено творчі вміння, які $\epsilon$ поліхудожними, ефективними й універсальними.

Висновки. Отже, формування творчих умінь майбутнього вчителя образотворчого мистецтва розглядається нами в аспекті підготовки нового типу вчителя, як творчої особистості зі збагаченими власними творчими вміннями, художніми цінностями європейської та світової якості. Творчі 
вміння вчитель реалізує в художньо-педагогічній діяльності, допомагаючи школярам формувати вміння, завдяки яким виконуються навчальні завдання.

\section{ЛІТЕРАТУРА:}

Антонович Є. А. Захарчук-Чугай Р. В., Станкевич М. С. Декоративно-прикладне мистецтво. Посібник. Львів: Світ. 1992. 270 с.

Лисенко Н. Educational Ideal of Ukrainian Ethnopedagogies. 3б. наук. праць. Полтава: ПНПУ імені В. Г. Короленка. 2018. Кн.1. С.441-447.

Програма розвитку вищої освіти України «Основні засади розвитку вищої освіти України» [ Текст] К. 2008. Ч.4

Сисоєва С. О. Основи педагогічної творчості: Підручник. К.: Міленіум, 2006. 344 с.

Щолокова О. П. Новітні підходи та технології у професійній підготовці вчителя мистецьких дисциплін. Innovative processes in education: Collective monograph. AMEET Sp. z.o.o., Lodz, Poland, 2017. P. 238-246.

\section{REFERENCES:}

Antonovych, Ye. A., Zakharchuk-Chuhai, R. V., Stankevych, M. S. (1992). Dekoratyvnoprykladne mystetstvo. [The decorative and applied art]. Lviv: Svit, [in Ukrainian].

Lysenko, N. (2018). Vykhovnyi ideal v Ukrainskii etnopedahohitsi [Educational Ideal of Ukrainian Ethnopedagogies]. Poltava: PNPU imeni V. H. Korolenka. 441-447. [in Ukrainian].

Programa rozvytku vishchoi osvity Ukrainy «Osnovni zasady rozvytku vishchoi osvity Ukrainy» (2008). [Development of higher educatson in Ukraine. The main features of development of higher education of Ukraine]. Kyiv. Ch.4. [in Ukrainian].

Shcholokova, O. P. (2017). Novitni pidkhody ta tekhnolohii u profesiinii pidhotovtsi vchytelia mystetskykh dystsyplin. [New approaches and technologies in the professional training of the teacher of artistic disciplines]. Innovative processes in education. Lodz, Poland, 238246 [in Ukrainian].

Sysoeva, S. O. (2006). Osnovy pedahohichnoi tvorchosti. [Basics of pedagogical art]. Kyiv: Millenium [in Ukrainian].

\begin{tabular}{|c|c|}
\hline Інформація про автора: & Information about \\
\hline $\begin{array}{l}\text { Пригодін Микола Дмитрович: ORCID: } \\
\text { https://orcid.org/0000-0002-6891-8585, } \\
\text { старший викладач кафедри українського }\end{array}$ & $\begin{array}{l}\text { Pryhodin Mykola Dmytrovych: } \\
\text { https://orcid.org/0000-0002-6891 } \\
\text { Lecturer of the Department of Uk }\end{array}$ \\
\hline декоративно-прикладного & Decorative and Applied A \\
\hline графіки, $\quad$ Харківський & S. Skovoroda Kharkiv National Pedagogical \\
\hline $\begin{array}{l}\text { Сковороди, вул. Валентинівська, } \\
\text { м. Харків, Україна, } 61166 . \\
\text { e-mail. russaouila } 1769 @ \text { omail com }\end{array}$ & $\begin{array}{l}\text { Ukraine } 61166 . \\
\text { e-mail: russaguila } 1769 \text { @ gmail.com }\end{array}$ \\
\hline
\end{tabular}

Цитуйте цю статтю як: Пригодін М. Д. Особливості формування творчих умінь майбутніх учителів образотворчого мистецтва в процесі аналізу творів мистецтва. Теорія та методика навчання та виховання. 2019. № 46. С. 122-130.

DOI: $10.34142 / 23128046.2019 .46 .09$

Дата надходження статті до редакції: 27.03.2019

Стаття прийнята до друку: 10.04.2019 